Submission Theme: Efficient and Sustainable Use of Construction Materials

Fifth International Conference on Sustainable Construction Materials and

Technologies. http://www.claisse.info/Proceedings.htm

\title{
SCMT5
}

Kingston University London, UK, July 14-17, 2019

\section{SULFATE RESISTANCE OF PORTLAND CEMENT MORTARS: A COMPARISON OF NANO AND MICRO SILICA Nader Ghafoori Ph. D. ${ }^{1}$, Iani Batilov, P.E. ${ }^{2}$, Meysam Najimi, Ph. D. ${ }^{3}$ \\ ${ }^{1}$ Professor, Dep. of Civil and Environmental Engineering and Construction, Univ. of Nevada Las Vegas, NV 89154, USA \\ ${ }^{2}$ Civil Engineer, Stantec Consulting Services, Las Vegas, NV 89102, USA \\ ${ }^{3}$ Postdoctoral Research Associate, Dep. of Civil, Construction and Environmental Engineering, Iowa State University, IA 50010, USA}

\begin{abstract}
Presented is a direct comparison sulfate resistance study of mortars, containing 3 or $6 \%$ cement replacement with either colloidal nanosilica $(\mathrm{nS})$ or microsilica $(\mathrm{mS})$, exposed to 26 weeks of full submersion in a $5 \%$ sodium sulfate $\left(\mathrm{Na}_{2} \mathrm{SO}_{4}\right)$ solution. Mortar bar samples prepared per ASTM C 490 and measured for linear expansion per ASTM C 1012 over the 6-month testing period indicated that at $6 \%$ cement replacement, colloidal $\mathrm{nS}$ exhibited on average $75 \%$ the expansion of the microsilica containing counterpart. At 3\% replacement, either form of silica reduced the sulfate attack related expansion to a similar degree (by 35 $\pm 2 \%$ ) in comparison to the control mixture. Supplemental rapid sulfate permeability testing (RSPT) supported the expansion results. The 6\% $\mathrm{nS}$ mortar mixture exhibited the least charge passed which indicated that the $\mathrm{nS}$ contained mortar were more impermeable in nature and more resistant to ion transport. SEM images taken of the $\mathrm{nS}$ and $\mathrm{mS}$ particles at similar levels of magnification visually revealed the significant difference in particle size between both forms of silica. Absorption testing per ASTM C 642 revealed a larger permeable pore volume in the $6 \% \mathrm{mS}$ containing mortar mixture in comparison to $6 \% \mathrm{nS}$. The smaller permeable pore volume of the $6 \% \mathrm{nS}$ mixture supports the physical paste densification effect observed with $\mathrm{nS}$ application in cementitious mixtures from other studies. Mercury intrusion porosimetry (MIP) tests of the control and 6\% silica containing mixtures, revealed evidence of paste and paste-to-aggregate interfacial zone densification, as well as pore size refinement. Through the use of $\mathrm{nS}$ and $\mathrm{mS}$, the void volume proportion of gel pores and capillary micropores in the silica containing mixtures increased in comparison to the control, and there was an overall reduction in the capillary macropores.
\end{abstract}

Keywords: nanosilica, microsilica, silica fume, pozzolan, durability, sulfate attack, sulfate resistance 


\section{INTRODUCTION \& BACKGROUND}

As succinctly yet effectively stated in a book on durable concrete, "structural failures are rare, but durability failures are all too common (Richardson 2002)." That is often the case when due consideration is not given to specifying concrete mixture designs well-suited for the environment under which the structure will be subjected to and achieving a long and ideally maintenance-free service life. In the recent years it has been well documented that cement production is the third-largest source of human generated $\mathrm{CO}_{2}$, and the global cement production has only accelerated having grown to more than 30-times that reported in 1950 (Andrew 2018). There is an economic and sustainable incentive to build durable structures using concrete mixture designs well-suited for the anticipated effects of weathering, abrasion, and exposure the chemical and physical assault from ASR, chlorides, or sulfates. The cost of repairing, protecting, and rehabilitating concrete infrastructure in the US alone is estimated to be upwards of \$21 billion (ICRI 2006). The ability to utilize the existing concrete structures up to and beyond their intended service life and allow for cost-effective retrofitting that does not require complete demolition and expenditure of the energy and resources required to demolish, dispose, and rebuild is now a major focus of research and development (Richardson 2002).

Silica fume or microsilica $(\mathrm{mS})$ as referred to from here out, is one of the well-known industry recognized supplementary cementitious materials (SCMs) used in the production of high-durability concrete (Kosmatka and Wilson 2016). Numerous research has been published since the pozzolanic byproduct, condensed from the $\mathrm{SiO}_{2}$ rich vapors of electric arc furnaces used in the silicon and ferrosilicon industry, was first collected and studied in Norway in the late 1940s and later brought to the US in the 1980s (ACI Committee 234 2006). Currently, $\mathrm{mS}$ is a code recognized pozzolan recommended by ACI 318 for concrete anticipated to come in contact with water or soil containing deleterious concentrations of sulfate that meet the S3 sulfate exposure classification (ACI Committee 318 2014). Nanosilica (nS) is among the collection of new engineered nanoscale materials investigated for use in cementitious materials and shown to improve concrete strength and durability properties (Du et al. 2014; Ghafoori et al. 2016; Sanchez and Sobolev 2010). Chemically it is very similar to $\mathrm{mS}$, as it is essentially nano-sized $(<100 \mathrm{~nm})$ silicon dioxide $\left(\mathrm{SiO}_{2}\right)$ particles. In comparison, $\mathrm{mS}$ particles are larger, typically $<1$ $\mu \mathrm{m}$ (Holland 2005). The smaller particle sizes of $\mathrm{nS}$ correlate with a specific surface area of 80 $\mathrm{m}^{2} / \mathrm{g}$ or more while that of $\mathrm{mS}$ is typically in the $15-25 \mathrm{~m}^{2} / \mathrm{g}$ range (Campillo et al. 2004). The higher surface area makes $\mathrm{nS}$ a much more reactive pozzolan that can rapidly and effectively limit available $\mathrm{Ca}(\mathrm{OH})_{2}$ for reaction with sulfates. Furthermore, $\mathrm{nS}$ has been shown to create seeding sites for the alite $\left(\mathrm{C}_{3} \mathrm{~S}\right)$ and belite $\left(\mathrm{C}_{2} \mathrm{~S}\right)$ phase during hydration that contributes to the growth of a more compact C-S-H phase and a densified cement paste to aggregate interfacial zone (Sanchez and Sobolev 2010; Singh et al. 2013).

External sources of either sodium-, potassium-, magnesium-, and calcium sulfate are common in the soil, groundwater, or seawater the concrete will be in contact with (Skalny et al. 2002). The effects of sulfate attack are expansion, spalling, softening, adhesion loss, and decalcification of the hydrated phases (Mehta 2000; Skalny et al. 2002; Wee et al. 2000). Sulfate attack could compromise the protective concrete cover and increase permeability which will result in more significant issues once a path to the reinforcement steel is established and corrosion begins. It was the objective of the researchers to evaluate if $\mathrm{nS}$ would offer a 
comparable or superior performance to $\mathrm{mS}$ when specifying pozzolan for durable concrete mixture designs intended for structures subject to severe sulfate exposure conditions.

\section{EXPERIMENTAL PROGRAM}

\section{Materials}

The Portland cement used was locally sourced and Type II per ASTM C 150 (ASTM International 2002a) with an inherently moderate sulfate resistance due to the limited $\mathrm{C}_{3} \mathrm{~A}$ content of $7.2 \%$. The $\mathrm{mS}$ was sourced from a US supplier in an undensified gray amorphous submicron powder form. The pozzolan met all chemical and physical requirements per ASTM C 1240 (ASTM International 2003a). The $\mathrm{nS}$ used was in the form of a commercially available aqueous dispersion containing $25 \%$ by weight $5-35 \mathrm{~nm}(0.197-1.378 \times 10-6 \mathrm{in})$ amorphous $\mathrm{nS}$ particles. The chemical and physical properties of the cement, microsilica, and nanosilica are presented in Table 1.

The fine aggregate used for the mortars in this study was from a Nevada based quarry and had an oven-dry specific gravity of 2.76 as measured by ASTM C 128 (ASTM International 2015), absorption of $0.81 \%$ and a fineness modulus of 2.64. Its gradation was well inside the upper and lower limits of ASTM C 33 (ASTM International 2003b). Commercially bottled distilled water purchased from a single source was used for mortar mixing and preparation of the 5\% sodium sulfate solution. A polycarboxylate based high-range water-reducing admixture (HRWRA) was utilized for achieving the desired flow per ASTM C 109 (ASTM International 2002b).

Table 1: Properties of Cementitious Materials

\begin{tabular}{|c|c|c|c|}
\hline & $\begin{array}{l}\text { Type II } \\
\text { Cement }\end{array}$ & $\begin{array}{l}\text { Microsilica } \\
\quad(\mathrm{mS})\end{array}$ & $\begin{array}{c}\text { Colloidal } \\
\text { Nanosilica } \\
\text { (AQnS) }\end{array}$ \\
\hline \multicolumn{4}{|l|}{ Chemical Composition } \\
\hline Silicon Dioxide $\left(\mathrm{SiO}_{2}\right), \%$ & 21.1 & 94.72 & 99.9 \\
\hline Aluminum Oxide $\left(\mathrm{Al}_{2} \mathrm{O}_{3}\right), \%$ & 4 & -- & -- \\
\hline Ferric Oxide $\left(\mathrm{Fe}_{2} \mathrm{O}_{3}\right), \%$ & 2 & -- & -- \\
\hline Calcium Oxide $(\mathrm{CaO}), \%$ & 62.7 & -- & -- \\
\hline Magnesium Oxide $(\mathrm{MgO}), \%$ & 2.1 & -- & -- \\
\hline Sulfur Trioxide $\left(\mathrm{SO}_{3}\right), \%$ & 2.8 & 0.23 & -- \\
\hline Loss on Ignition, $\%$ & 1.8 & 2.82 & -- \\
\hline Insoluble Residue, \% & 0.71 & -- & -- \\
\hline Total Alkali $\left(\mathrm{Na}_{2} \mathrm{O}+\mathrm{K}_{2} \mathrm{O}\right), \%$ & 0.59 & 0.49 & -- \\
\hline Free Lime $(\mathrm{CaO}), \%$ & 0 & & \\
\hline \multicolumn{4}{|l|}{ Physical Properties } \\
\hline Time of Set Initial Vicat, min & 145 & -- & -- \\
\hline Specific Surface Area, $\mathrm{m}^{2} / \mathrm{g}$ & $0.341^{\mathrm{a}}$ & $22.65^{\mathrm{b}}$ & -- \\
\hline $325 \mathrm{Mesh}(45 \mu \mathrm{m}), \%$ passing & -- & 97.12 & \\
\hline Avg. Particle Size (APS), $\mu \mathrm{m}$ & $20-30^{\mathrm{c}}$ & $0.1-1.0^{\mathrm{c}}$ & $\begin{array}{c}0.005- \\
0.035\end{array}$ \\
\hline \multicolumn{4}{|l|}{ Per Bogue Calculation ${ }^{d}$} \\
\hline Tricalcium Silicate $\left(\mathrm{C}_{3} \mathrm{~S}\right), \%$ & 57.0 & -- & -- \\
\hline
\end{tabular}




\begin{tabular}{|c|c|c|c|}
\hline Dicalcium Silicate $\left(\mathrm{C}_{2} \mathrm{~S}\right), \%$ & 17.5 & -- & -- \\
\hline Tricalcium Aluminate $\left(\mathrm{C}_{3} \mathrm{~A}\right), \%$ & 7.2 & -- & -- \\
\hline $\begin{array}{l}\text { Tetracalcium Aluminoferrite } \\
\left(\mathrm{C}_{4} \mathrm{AF}\right), \%\end{array}$ & 6.1 & -- & -- \\
\hline $\begin{array}{l}\text { aby Blaine air-permeability test } \\
\text { b by BET Analysis } \\
\text { 'Estimated from MasterSizer Par } \\
\text { dBogue Modified Equation for In }\end{array}$ & $\begin{array}{l}\text { tributi } \\
\text { d Gyp }\end{array}$ & mest & 2012) \\
\hline $\begin{array}{l}1 \mu \mathrm{m} \\
\mathrm{ft}^{2} / \mathrm{lb}\end{array}$ & 1879 & & \\
\hline
\end{tabular}

\section{Mixture Design}

A total of five mortar mixtures were tested within the scope of this study, one control mixture with no pozzolan content and two mixtures with either $3 \%$ or $6 \%$ cement replacement with $\mathrm{mS}$ or $\mathrm{nS}$. The mixture proportions are presented in Table 2 . The water-to-binder ratio $(\mathrm{w} / \mathrm{b})$ was kept at a constant 0.485 for all mixtures according to ASTM C 1012 (ASTM International 2004). The fine aggregate-to-binder ratio was 2.75-to-1 by mass as specified in ASTM C 109 (ASTM International 2002b).

Table 2: Mortar Mixture Proportions

\begin{tabular}{|c|c|c|c|c|c|c|c|}
\hline \multirow[b]{2}{*}{$\begin{array}{l}\text { Mixture } \\
\text { Designation }\end{array}$} & \multicolumn{3}{|c|}{ Binder Content, \% } & \multirow[b]{2}{*}{$\begin{array}{l}\text { Measured } \\
\text { Flow, \%* }\end{array}$} & \multirow{2}{*}{$\begin{array}{l}\text { HRWRA } \\
\text { Used, } \\
\text { mL }\end{array}$} & \multicolumn{2}{|c|}{ 3-Day Compressive } \\
\hline & Cement & $\mathrm{nS}$ & $\mathrm{mS}$ & & & $\begin{array}{c}\text { Strength, } \\
\text { psi }\end{array}$ & $\mathrm{MPa}$ \\
\hline CNTL & 100 & -- & -- & $148 \%$ & 0.0 & 4,296 & 29.6 \\
\hline $3 \mathrm{mS}$ & 97 & -- & 3 & $108 \%$ & 0.0 & 4,420 & 30.5 \\
\hline $6 \mathrm{mS}$ & 94 & -- & 6 & $95 \%$ & 4.0 & 4,463 & 30.8 \\
\hline 3AQnS & 97 & 3 & -- & $80 \%$ & 13.0 & 6,290 & 43.4 \\
\hline 6AQnS & 94 & 6 & -- & $49 \%$ & 30.0 & 6,473 & 44.6 \\
\hline
\end{tabular}

*Flow measured according to ASTM C 1437 with flow table conforming to ASTM C 230

\section{Mixing Procedure and Curing}

The mixtures were prepared in an epicyclic mechanical mixer following the mortar preparation procedure of ASTM C 305 (ASTM International 1999). Before combining the binder with water and starting the mortar mixing regimen, the $\mathrm{mS}$ was homogeneously intermixed with the cement by hand, or in the case of the colloidal $\mathrm{nS}$, combined with the mixing water before adding the cement to the mixer bowl. For each of the design mixtures, four mortar expansion bars were prepared per ASTM C 1012, $5 \mathrm{~cm}$ (2-in) mortar cubes specimens were prepared per ASTM C 109 for strength testing, and six $10 \mathrm{~cm}$ (4-in), diameter disks for supplemental testing. For the $\mathrm{nS}$ and $\mathrm{mS}$ replacement mixtures, addition of HRWRA was required to achieve workability as close to the ASTM C 109 recommendation as possible. HRWRA dosages and flow measurements are 
presented in Table 2. All mortar sample molds were manually filled and compacted using an electromagnetic vibrating table. The sample molds for each mortar mixture were then plastic wrapped and kept at room temperature $\left(21 \pm 3{ }^{\circ} \mathrm{C}\right)$ for 24 hours. Curing was continued for 3 days in a moist room to achieve the required compressive strength of $20 \pm 1.0 \mathrm{MPa}(2900 \pm 145 \mathrm{psi})$ per ASTM C 1012 prior to sulfate exposure. Following the 3-day curing period, the mortar bars were transferred to a 5\% sodium sulfate solution tank. Disks were kept in the moist curing room prior to using them for the absorption and RSPT tests.

\title{
Sulfate Solution
}

The 5\% sodium sulfate solution was prepared per the outlined procedure in ASTM C 1012 (ASTM International 2004). The tank size selected and volume of solution prepared were sufficient to maintain all samples fully submerged and meet the recommended minimum solution to mortar volume ratio of 4 . The solution in each container was kept in circulation using submersible pumps and the $\mathrm{pH}$ was continuously rebalanced to maintain $6.5 \pm 1$ using a $\mathrm{pH}$ controller and peristaltic pump system that dosed $0.5 \mathrm{~N} \mathrm{H}_{2} \mathrm{SO}_{4}$ as needed during the 6 month fully submerged test. The latter measure maintains solution acidity and replenishes the available sulfate ion concentration as established in prior existing studies (Mehta 1975).

\section{Expansion}

The four mortar bars prepared for each mixture design were measured in a length comparator with a digital gage following the ASTM C 1012 frequency and measurement procedure. When measured, the mortar bars for each mixture were kept immersed in a portable container filled with sulfate solution from the main test tank to avoid any effects from drying and shrinkage. The reported length change values were calculated as directed in ASTM C 490 (ASTM International 2000) and based on the average between the four bars at each age.

\begin{abstract}
Absorption
Three of the mortar disk specimens prepared were used for the water absorption test after 28 days of curing. The test procedure and calculation of the volume of permeable pore space percentage followed ASTM C 642 (ASTM International 1997). The values presented in the results are based on an average.
\end{abstract}

\section{Rapid Sulfate Permeability Test (RSPT)}

The RSPT is a performance-based six-hour test recommended by the Cement Concrete \& Aggregates Australia in a technical note on developing performance-based specifications for sulfate-resisting concrete (CCAA 2011) originally proposed by Tumidajski and Turc (Tumidajski and Turc 1995). The test method is analogous to the rapid chloride permeability test (RCPT) per ASTM C 1202 (International 1997). Instead of 3\% NaCl solution on one face of the specimen across the $0.3 \mathrm{~N} \mathrm{NaOH}$ solution, the RSPT test utilizes a $10 \% \mathrm{Na}_{2} \mathrm{SO}_{4}$ solution. The test was performed on mortar disks at the same 28-day curing age as done so for absorption.

\section{Mercury Intrusion Porosimetry (MIP)}

Mortar fragments no larger than $15 \mathrm{~cm}^{3}$ were collected from the center of samples to avoid any mold effects, and then oven dried and vacuum desiccated to prepare them for the MIP test. The samples were collected from cubes that had cured the full 6 months and were not exposed to sulfate solution so that the precipitation of sulfate attack related compounds do not factor into the porosity and pore size distribution of the tested mixtures. 


\section{Field Emission Scanning Electron Microscopy (FESEM)}

For the images of the nano- and microsilica, a model JSM-6700F Field Emission Scanning Electron Microscope (FESEM) with a magnification range of $x 500$ to $x 430,000(5 \mu \mathrm{m}$ to $10 \mathrm{~nm})$ was used (see Figure 1). Small samples of the pozzolan were then gold coated with a thin, approximately $20 \mathrm{~nm}$, layer of gold for conductance using an automated sequence sputter coating machine. The $\mathrm{nS}$ sample was the collected residue remaining after a few drops of colloidal $\mathrm{nS}$ were left to evaporate.

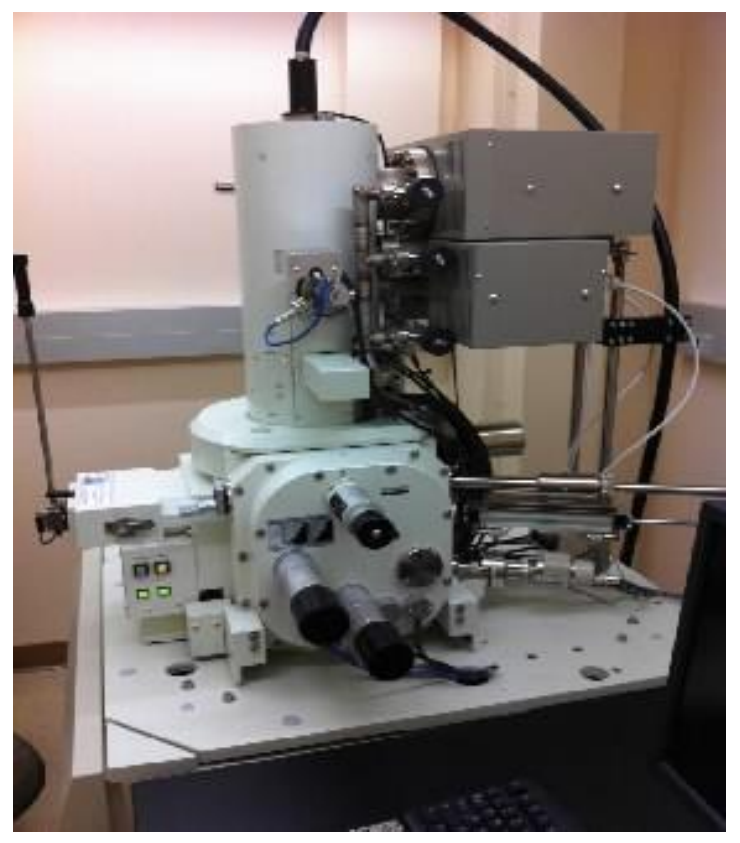

Figure 1: FESEM Used for Imaging of $\mathrm{mS}$ and Colloidal $\mathrm{nS}$

\section{RESULTS AND DISCUSSION}

The expansion readings recorded for each mortar mixture are presented in Figure 2 and summarized in Table 3 for select period of exposure that will be referenced in the discussion. By the fourth week of exposure in the sulfate solution, the pozzolan containing mixtures discernably exhibited less expansion in comparison to the cement only CNTL mixture. At four weeks exposure, the $3 \mathrm{mS}$ and $6 \mathrm{mS}$ mixtures exhibited $77.3 \%$ and $90.9 \%$ of the expansion observed with the CNTL, respectively. The AQ3nS and AQ6nS mixtures even more so, showing only $69.7 \%$ and $48.5 \%$ the expansion compared to the CNTL. Lower levels of expansion correlate to a higher resistance to external sulfate attack. With $\mathrm{Na}_{2} \mathrm{SO}_{4}$ as the sulfate source, the expansion due to sulfate attack is the effect of excessive gypsum and ettringite formation, both products of the chemical reactions between sulfate ions $\left(\mathrm{SO}_{4}^{-2}\right)$ and hydrated cement phases (Hewlett and Massazza 2003; Skalny et al. 2002). 
Table 3: Expansion Measurements at Select Periods of Exposure

\begin{tabular}{lccccc}
\hline & \multicolumn{5}{c}{ Expansion, \% } \\
\cline { 2 - 6 } $\begin{array}{l}\text { Duration of } \\
\text { Exposure }\end{array}$ & CNTL & $3 \mathrm{mS}$ & $6 \mathrm{mS}$ & AQ3nS & AQ6nS \\
\hline \hline $\begin{array}{l}4 \text { weeks } \\
8 \text { weeks }\end{array}$ & 0.011 & 0.009 & 0.010 & 0.008 & 0.005 \\
$\begin{array}{l}\text { 12 weeks (3 } \\
\text { months) }\end{array}$ & 0.016 & 0.012 & 0.015 & 0.014 & 0.011 \\
$\begin{array}{l}\text { 26 weeks (6 } \\
\text { months) }\end{array}$ & 0.021 & 0.017 & 0.017 & 0.015 & 0.013 \\
\hline
\end{tabular}

*Expansion values are rounded to the nearest thousandth.

Over the duration of the experiment, the $\mathrm{mS}$ and $\mathrm{nS}$ containing mortar bars continued to exhibit less expansion over the CNTL, yet after 3 months of exposure it became apparent that the expansion of the $3 \mathrm{mS}$ and $6 \mathrm{mS}$ mortars was very comparable. The percent difference between the two over the first 8 weeks averaged 19\%, that difference dropped to a mere $3 \%$ by then end of the test period. Doubling the $\mathrm{mS}$ replacement content did not result in any improvements in sulfate resistance. On the other hand, the increase of the colloidal $\mathrm{nS}$ content from $3 \%$ to $6 \%$ had a positive effect on the sulfate resistance for that mortar mixture when compared to AQ3nS. Consistently, AQ6nS exhibited less expansion that AQ3nS, on average approximately $80 \%$ that of AQ3nS. At 6 months, AQ6nS exhibited an expansion of $0.023 \%$ and AQ3nS showed $0.027 \%$, that is a $16 \%$ difference.

Comparing the two pozzolans, at $3 \%$ replacement, $\mathrm{mS}$ and $\mathrm{AQnS}$ showed very similar levels of expansion as evident in Figure 2. The expansion measurements of mortar mixture $3 \mathrm{mS}$ and AQ3nS were $71.8 \%$ and $69.2 \%$ that of the CNTL, respectively, a mere $4 \%$ difference. As stated earlier, at the larger $6 \%$ replacement, the $\mathrm{mS}$ mixture performed very similarly to the $3 \% \mathrm{mS}$, and therefore was surpassed by AQ6nS. The $6 \%$ colloidal $\mathrm{nS}$ mixture exhibited an expansion of $0.023 \%$, that was $59 \%$ the expansion of the CNTL at 6 months and the largest improvement in sulfate resistance. In comparison, $6 \mathrm{mS}$ exhibited $71.8 \%$ the expansion of CNTL which was almost identical to that of $3 \mathrm{mS}$. 


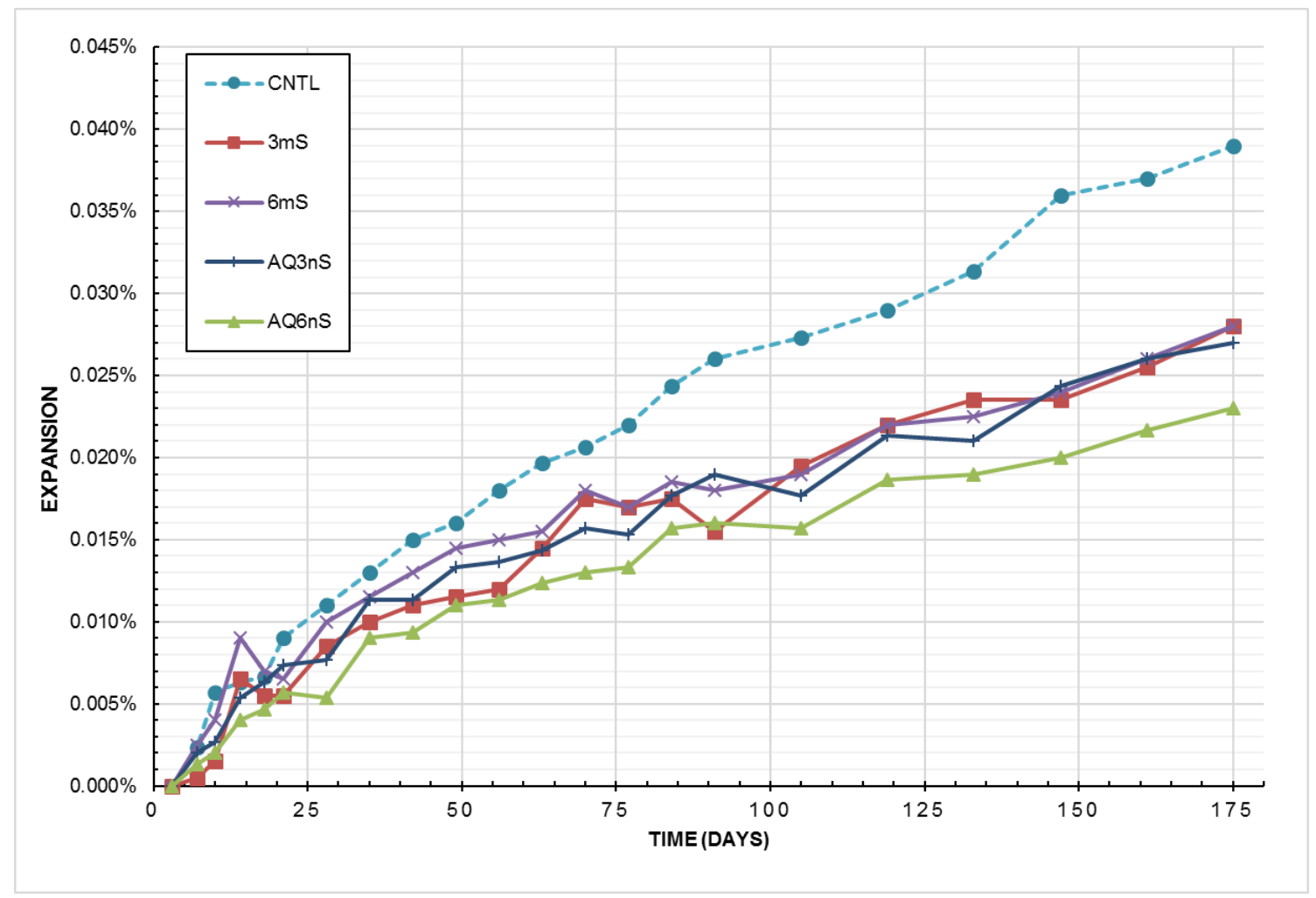

Figure 2: Expansion Measurements Over 6-Month Testing Period

The expansion results were supported by the RSPT test which reflects both the interconnectivity of the mixture's pore structure and free ion movement (Stanish et al. 1997; Tumidajski and Turc 1995). The electrochemical conductance test results, reported as total charge passed in Coulombs, reflects the permeability and diffusivity of all ions through the mortar matrix which includes free sulfate $\left(\mathrm{SO}_{4}{ }^{-2}\right)$, hydroxide $\left(\mathrm{OH}^{-}\right)$, and calcium $\left(\mathrm{Ca}^{+2}\right)$ ions (Stanish et al. 1997). The mobility of these ions would reflect how effective the pozzolan present in each mixture was at reducing the $\mathrm{Ca}(\mathrm{OH})_{2}$ available for reaction with the sulfate ions. The CNTL mixture had the highest charge passed which corroborates the highest measured expansion under sulfate attack. The mixtures with the higher $6 \%$ replacement of $\mathrm{mS}$ or colloidal $\mathrm{nS}$ also measured lower Coulomb readings, indicating reduction in the permeability and free ion availability and/or mobility through the sample. AQ6nS which had the lowest measured expansion under the 6 months of sulfate attack also had the lowest RSPT measurement of 612 Coulomb. This indicated that the $\mathrm{nS}$ contained mortar mixtures were more impermeable in nature and more resistant to ion transport. Likely a larger portion of the $\mathrm{Ca}(\mathrm{OH})_{2}$ was bound as secondary $\mathrm{C}-\mathrm{S}-\mathrm{H}$ due to the more active pozzolanic reactivity of the colloidal $\mathrm{nS}$ in comparison to $\mathrm{mS}$. This higher reactivity is driven by nanosilica's higher surface area per gram, $640+\mathrm{m}^{2} / \mathrm{g}$ for the colloidal $\mathrm{nS}$ used in this study versus $22.65 \mathrm{~m}^{2} / \mathrm{g}$ for the $\mathrm{mS}$. Nanosilica particles have a significantly higher surface area compared to $\mathrm{mS}$ due to their smaller size. The FESEM images taken of the $\mathrm{nS}$ and $\mathrm{mS}$ at similar levels of magnification visually revealed the significant difference in particle size between both forms of silica, see Figure 4 and Figure 5. The presence of a more reactive pozzolanic compound in the cementitious matrix limits the availability of calcium $\left(\mathrm{Ca}^{+2}\right)$ and hydroxide $\left(\mathrm{OH}^{-}\right)$ions freed by the more soluble $\mathrm{Ca}(\mathrm{OH})_{2}$ for reaction with sulfates, thus resulting in lower expansion due to reduced formation of deleterious gypsum and ettringite. 
Submission Theme: Efficient and Sustainable Use of Construction Materials

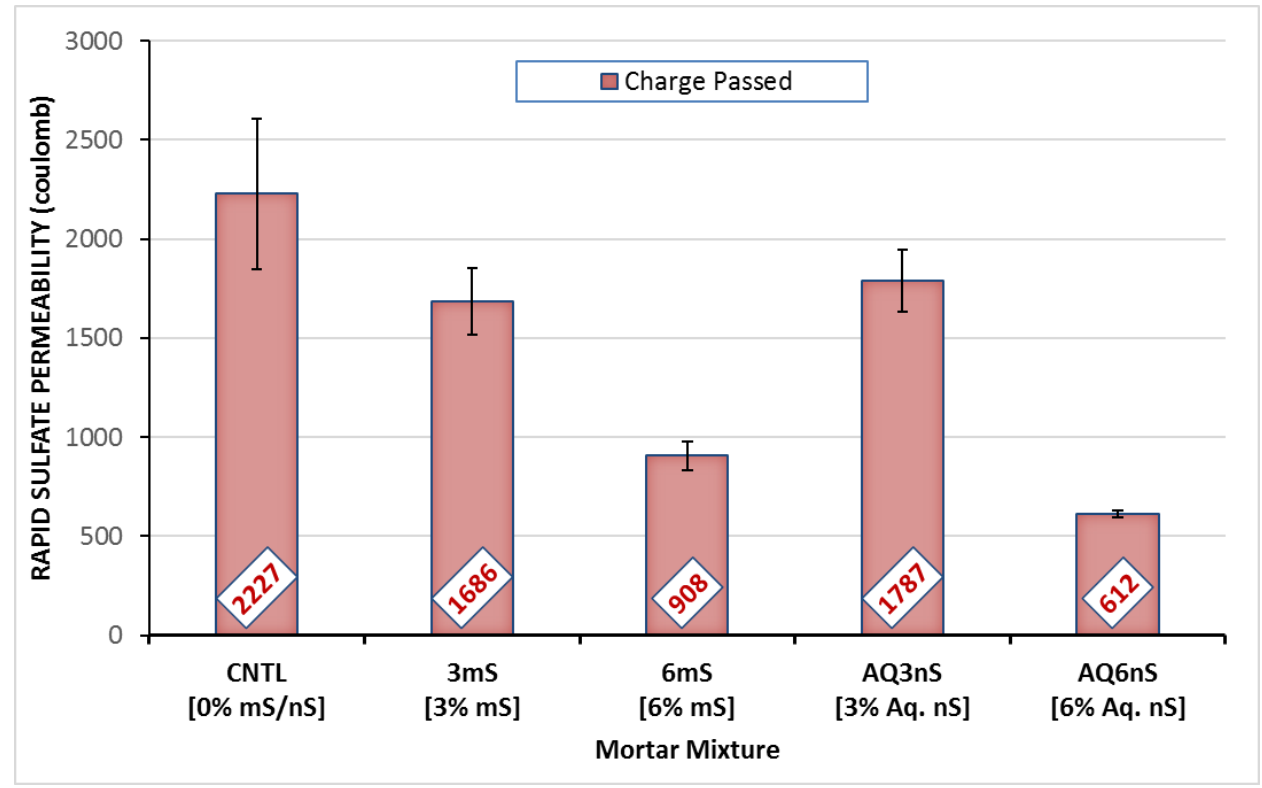

Figure 3: RSPT Results for Mortar Mixtures

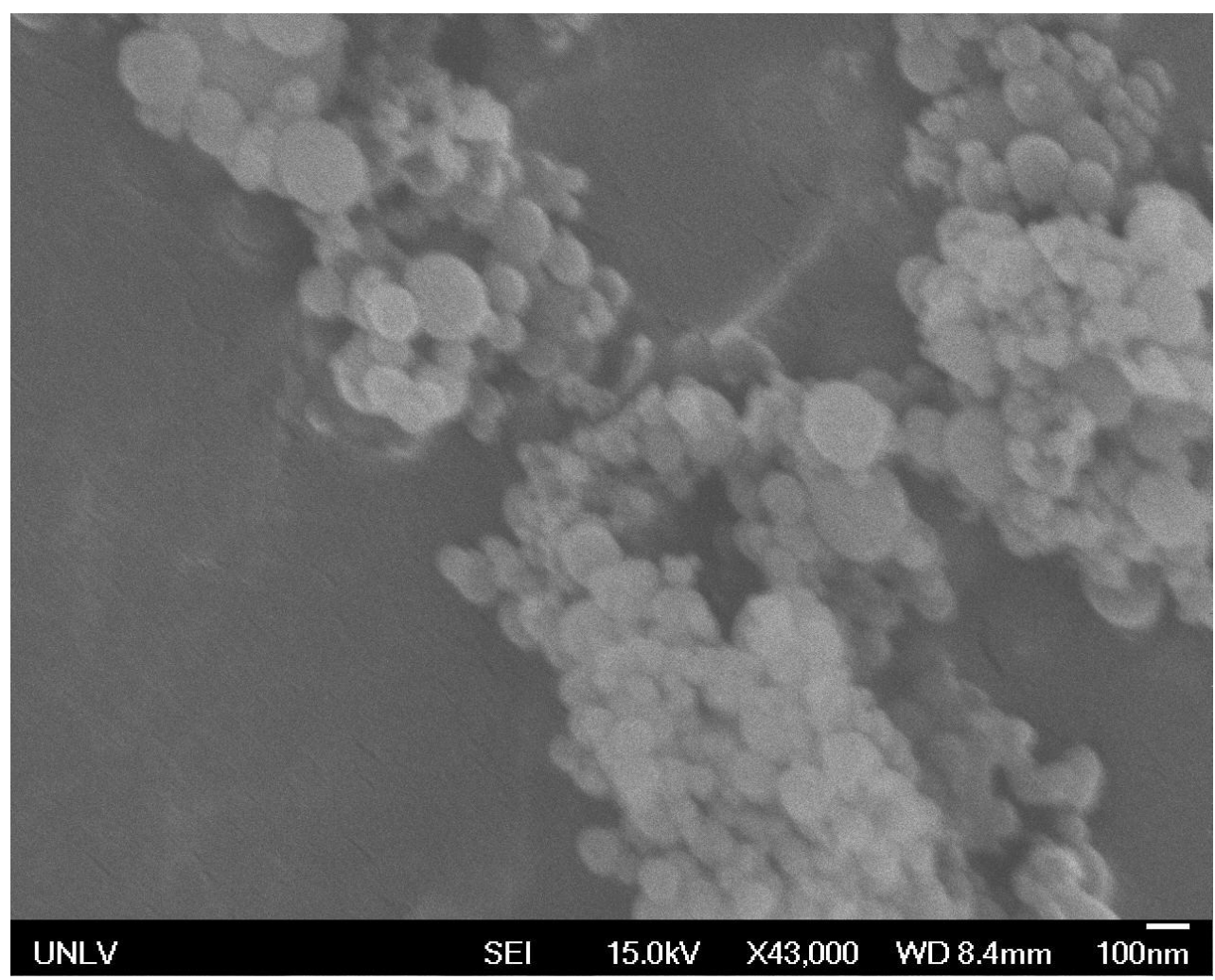

Figure 4: FESEM of Silica Fume (Microsilica) 


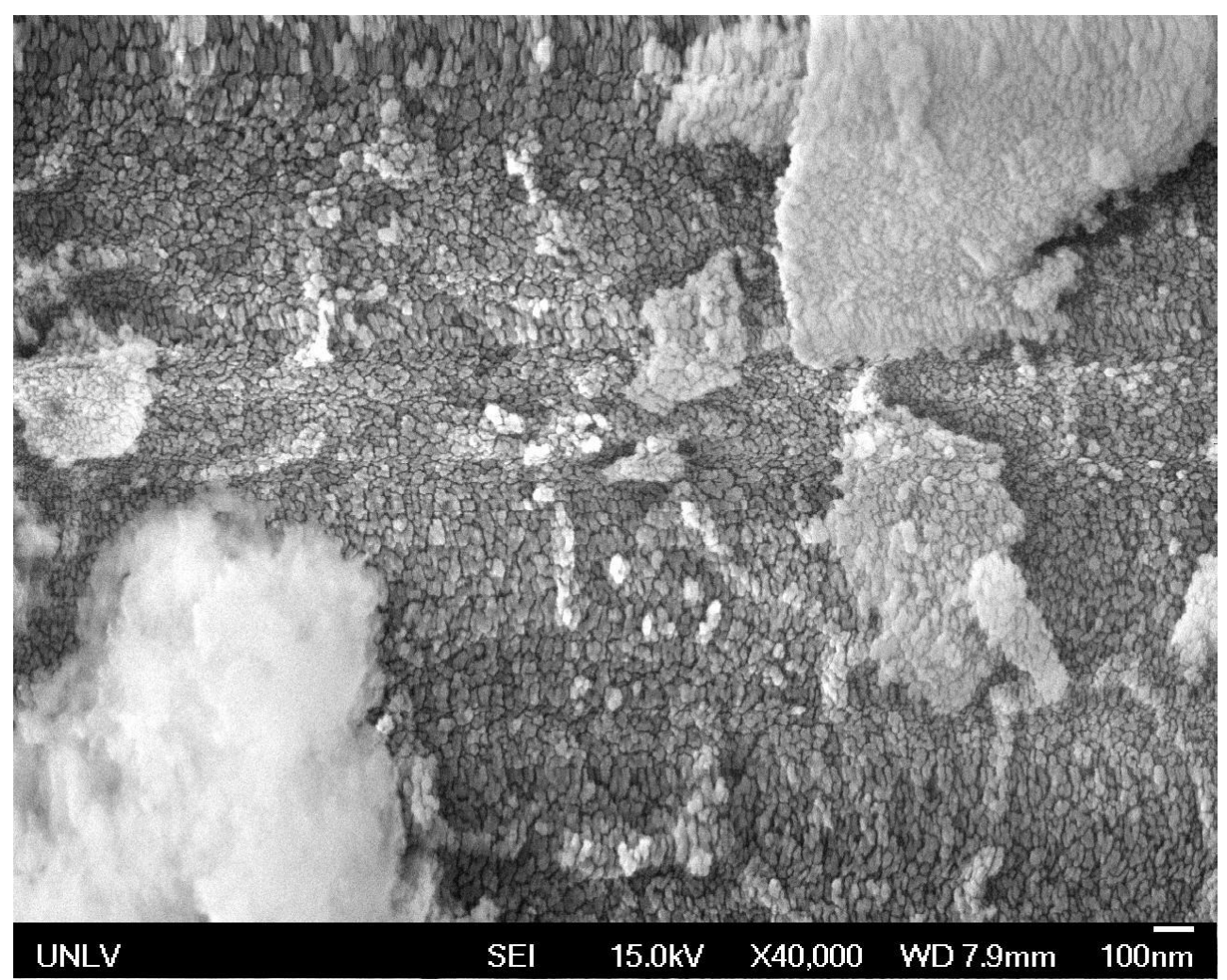

Figure 5: FESEM of Colloidal Nanosilica

The RSPT test showed a reduction in total charge passed between $3 \mathrm{mS}$ and $6 \mathrm{mS}$ but that reduction was not similarly reflected in the expansion measurements (i.e. $3 \mathrm{mS}$ and $6 \mathrm{mS}$ experienced similar expansion). The absorption test, the results of which are presented in Figure 6 , offered an explanation. The $6 \mathrm{mS}$ mortar showed an increase in the total volume of permeable pore space in comparison to $3 \mathrm{mS}, 10.48 \%$ versus $9.82 \%$. As with pure water used for the absorption test, the increased total volume of permeable voids allowed a larger quantity of sulfate solution to penetrate within the mortar sample counteracting the positive influence of $\mathrm{mS}$ in reducing available calcium hydroxide. In fact, the results of the absorption test showed that more sulfate solution penetrated and was available for expansive reaction in $6 \mathrm{mS}$ than $3 \mathrm{mS}$ due to its more permeable microstructure. On the other hand, the results of RSPT test proved that less calcium hydroxide was available in $6 \mathrm{mS}$ than $3 \mathrm{mS}$ as a result of a higher degree of pozzolanic reactions in $6 \mathrm{mS}$ than $3 \mathrm{mS}$. As sulfate and calcium hydroxide are the two primary components for the expansive reactions, their effects counteracted each other resulting in a similar expansion for $3 \mathrm{mS}$ and $6 \mathrm{mS}$. Were the pozzolanic effects of $\mathrm{nS}$ and $\mathrm{mS}$ nullified, the mixture with the higher permeable pore space would have likely exhibited more expansion than the CNTL.

The opposite effect can be observed with AQ3nS which also had similar expansion to 6mS. With AQ3nS the pozzolanic content was likely not enough which is why it had a larger coulomb reading than $6 \mathrm{mS}$. In lieu of that, the mixture had a smaller volume of permeable pores of $9.20 \%$ compared to $6 \mathrm{mS}$, so its pore structure was physically more impermeable to sulfate ingress and, in the end, exhibited similar expansion readings to $6 \mathrm{mS}$. The absorption test also validated the better sulfate resistance of the AQ6nS mixture. The smaller permeable pore volume of the $6 \%$ colloidal $\mathrm{nS}$ mixture supports the physical paste densification effect observed with nanosilica 
applications in cementitious mixtures from other studies (Quercia and Brouwers 2010; Senff et al. 2010; Singh et al. 2013).

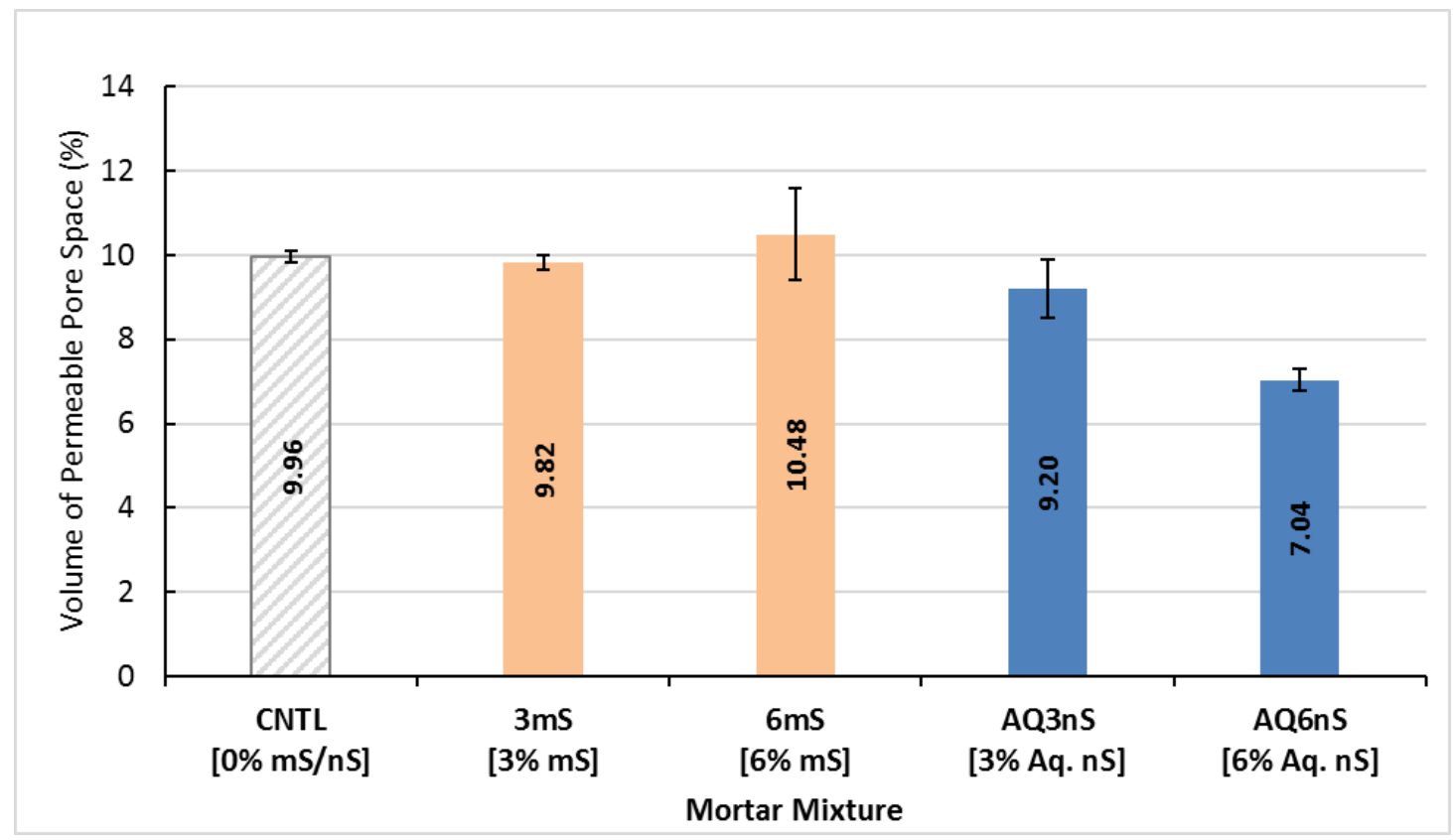

Figure 6: Absorption Results for Mortar Mixtures

Through supplemental MIP testing of the control, $6 \% \mathrm{mS}$ and $6 \%$ colloidal $\mathrm{nS}$ containing mixtures, there is evidence of paste and paste-to-aggregate interfacial zone densification, as well as pore size refinement. Pore sizes in hydrated cement paste have been grouped and classified depending their effect on the strength, permeability and durability properties (Mindess et al. 2003; Neville 1998). A mortar may have a higher porosity as measured by absorption, but it may be composed of smaller more tortuous and impermeable voids or larger entrapped air voids that do not facilitate the generation of the expansive stresses that lead to volume instability and cracking from sulfate attack (Richardson 2002). Gel pores ( $\leq 5 \mathrm{~nm}[0.005 \mu \mathrm{m}]$ ) are integral to the $\mathrm{C}-\mathrm{S}-\mathrm{H}$ phase and do not contribute to transport properties. Pores ranging from 5 to $50 \mathrm{~nm}(0.005$ $-0.050 \mu \mathrm{m}$ ) are considered capillary micropores and although tortuous, these can in small part contribute to permeability. The bulk of permeability and diffusivity occurs in the capillary macropores ranging from $50-10,000 \mathrm{~nm}(0.05$ to $50 \mu \mathrm{m})$ that are more likely to offer pore interconnectivity (Du et al. 2014; Tobón et al. 2015).

Referring to Figure 7, the void volume proportion of gel pores and capillary micropores for $6 \mathrm{mS}$ and AQ6nS are larger in comparison to the CNTL mixture as is evident by the raised pore size distribution curves for $6 \mathrm{mS}$ and AQ6nS within the gel pore and micropore range. Within the capillary macropore range there is also a shift of the pore size distribution to the left towards smaller diameter pore sizes likely less conducive to permeability. Total intrusion volumes are presented in Figure 8, there is an overall reduction in the volume of capillary macropores for both pozzolan containing mixtures in comparison to the CNTL. Both $6 \mathrm{mS}$ and AQ6nS also reflect the increase on the total volume of gel pores as was noted in Figure 7 which attests to the pozzolanic activity responsible for producing additional C-S-H phase. 
Submission Theme: Efficient and Sustainable Use of Construction Materials

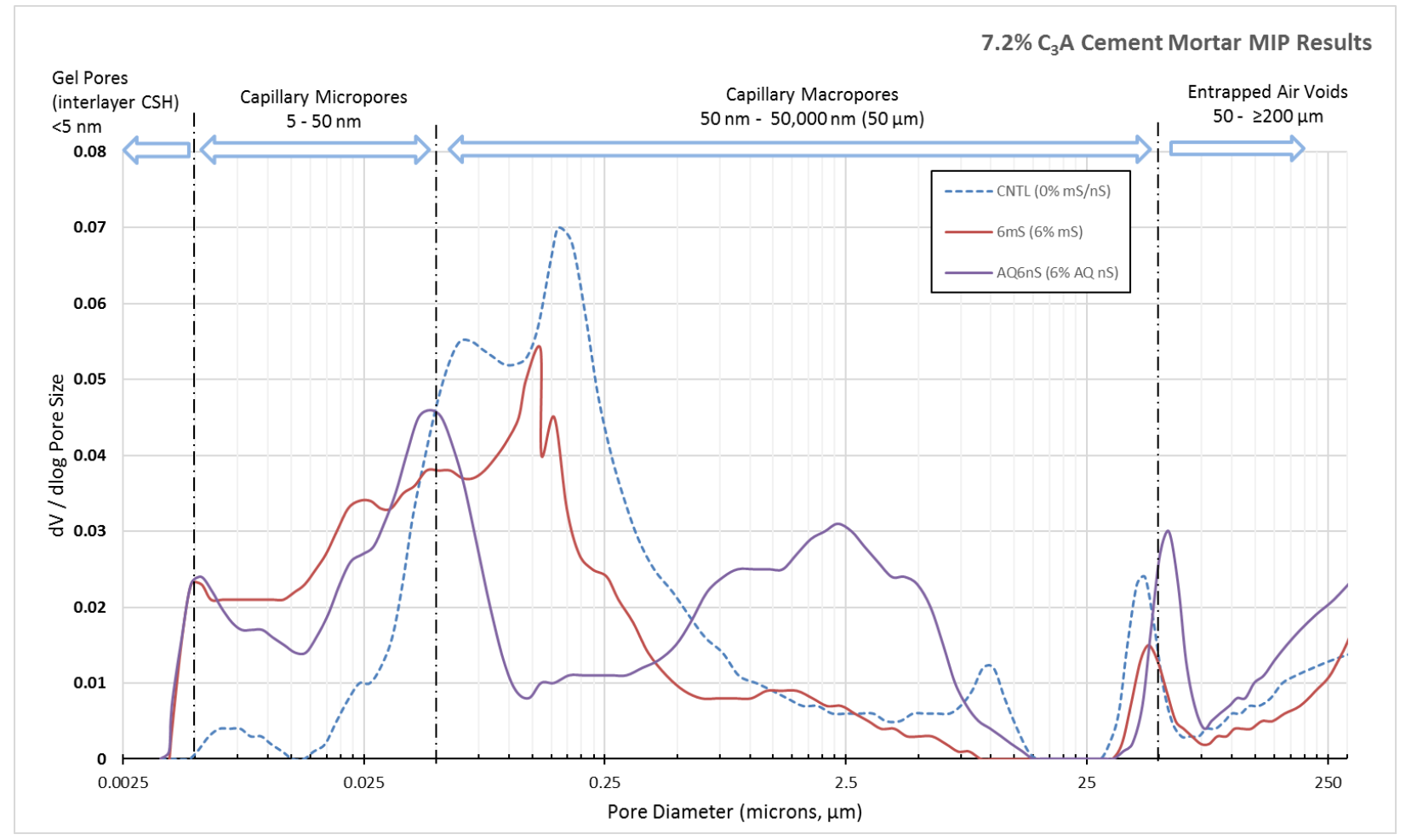

Figure 7: MIP Pore Diameter Distribution for CNTL, 6mS, and AQ6nS

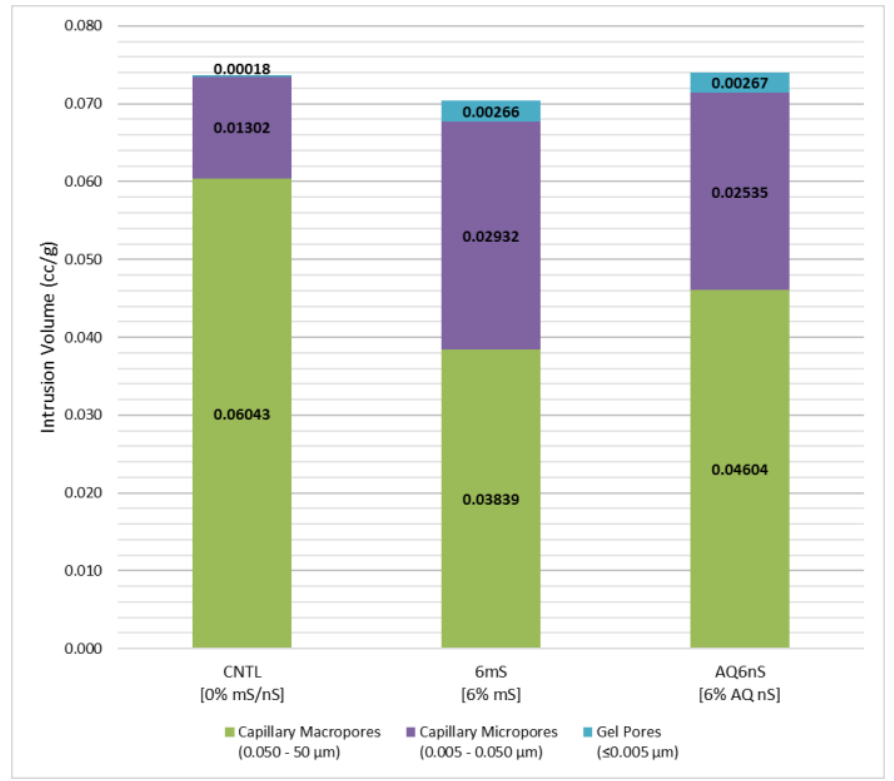

Figure 8: MIP Intrusion Volume in CNTL, 6mS, and AQ6nS 


\section{CONCLUSION}

The following observations can be made from this study:

- Mortar bar sample expansion measurements over the testing period indicated that at $6 \%$ cement replacement, colloidal $\mathrm{nS}$ exhibited less expansion that the $\mathrm{mS}$ containing counterpart. Lower levels of expansion correlate to a higher resistance to external sulfate attack.

- At 3\% replacement either form of silica reduced sulfate attack related expansion to a similar degree in comparison to the control. The expansion results indicate that at smaller doses $\mathrm{mS}$ would offer comparable performance to colloidal $\mathrm{nS}$. At higher levels of replacement, the benefits of the nanoscale sized silica particles resulted in measurably superior sulfate durability performance in comparison to $\mathrm{mS}$.

- The RSPT testing support the expansion results, the $\mathrm{nS}$ contained mortar mixtures were more impermeable in nature and more resistant to ion transport. Likely more of the $\mathrm{Ca}(\mathrm{OH})_{2}$ was bound as secondary C-S-H due to the more active pozzolanic reactivity of the $\mathrm{nS}$ comparison to $\mathrm{mS}$.

- Absorption testing revealed that there is a larger volume of permeable pore space in the $6 \% \mathrm{mS}$ containing mortar mixture in comparison to the $6 \%$ colloidal $\mathrm{nS}$ containing mixture. The smaller permeable pore volume of the $6 \% \mathrm{nS}$ mixture supports the physical paste densification effect observed with nanosilica applications in cementitious mixtures from other studies.

- Mercury intrusion porosimetry (MIP) tests of the control and 6\% silica containing mixtures, indicated evidence of paste and paste-to-aggregate interfacial zone densification, as well as pore size refinement. The void volume proportion of gel pores and capillary micropores increased in comparison to those of the control, and there was an overall reduction in the capillary macropores.

\section{REFERENCES}

ACI Committee 234. (2006). 234R-06 Guide for the Use of Silica Fume in Concrete.

ACI Committee 318. (2014). ACI 318-14 Building Code Requirements for Structural Concrete. Farmington Hills, MI.

Andrew, R. M. (2018). "Global CO2 Emissions from Cement Production." Earth System Science Data, 10(1), 195-217.

ASTM International. (1997). "ASTM C 642 Standard Test Method for Density, Absorption, and Voids in Hardened Concrete." Annual Book of ASTM Standards, 1-3.

ASTM International. (1999). ASTM C 305 Standard Practice for Mechanical Mixing of Hydraulic Cement Pastes and Mortars of Plastic Consistency. West Conshohocken, PA. ASTM International. (2000). ASTM C 490 Standard Practice for Use of Apparatus for the Determination of Length Change of Hardened Cement Paste, Mortar, and Concrete. 
Submission Theme: Efficient and Sustainable Use of Construction Materials

Annual Book of ASTM Standards, West Conshohocken, PA.

ASTM International. (2002a). ASTM C 150 Standard Specification for Portland Cement. Annual Book of ASTM Standards, West Conshohocken, PA.

ASTM International. (2002b). ASTM C 109/C 109M Standard Test Method for Compressive Strength of Hydraulic Cement Mortars. Annual Book of ASTM Standards, West Conshohocken, PA.

ASTM International. (2003a). ASTM C 1240 Standard Specification for Silica Fume Used in Cementitious Mixtures. Annual Book of ASTM Standards, West Conshohocken, PA.

ASTM International. (2003b). ASTM C 33 Standard Specification for Concrete Aggregates. West Conshohocken, PA.

ASTM International. (2004). ASTM C 1012 Standard Test Method for Length Change of Hydraulic-Cement Mortars Exposed to a Sulfate Solution. West Conshohocken, PA.

ASTM International. (2015). ASTM C128-15 Standard Test Method for Relative Density (Specific Gravity) and Absorption of Fine Aggregate. West Conshohocken, PA.

Campillo, I., Dolado, J. S., and Porro, A. (2004). "High-Performance Nanoestructured Materials for Construction." Nanotechnology in Construction, W. Z. Peter J M Bartos, John J Hughes, Pavel Trtik, ed., The Royal Society of Chemistry, London, 215-225.

CCAA. (2011). Technical Note: Sulfate-Resisting Concrete. Australia.

Du, H., Du, S., and Liu, X. (2014). "Durability performances of concrete with nano-silica." Construction and Building Materials, Elsevier Ltd, 73(12), 705-712.

Ghafoori, N., Batilov, I. B., and Najimi, M. (2016). "Sulfate Resistance of Nanosilica and Microsilica Contained Mortars.” ACI Materials Journal, 113(4), 459-469.

Hewlett, P. C., and Massazza, F. (2003). "Lea's Chemistry of Cement and Concrete." Lea's Chemistry of Cement and Concrete.

Holland, T. C. (2005). "Silica Fume User's Manual.” FHWA-IF-05-016, 194.

ICRI. (2006). "Vision 2020 : A Vision for the Concrete Repair Protection and Strengthening Industry." International Concrete Repair Institute, Chicago, IL, 1-25.

International, A. (1997). ASTM C 1202 Standard Test Method for Electrical Indication of Concrete's Ability to Resist Chloride Ion Penetration. West Conshohocken, PA.

Kosmatka, S. H., and Wilson, M. L. (2016). Design and Control of Concrete Mixtures. Portland Cement Association, Skokie, Illinois.

Mehta, P. K. (1975). "Evaluation of Sulfate-Resisting Cements by a New Test Method." ACI Journal Proceedings, 72(10), 573-575.

Mehta, P. K. (2000). "Sulfate Attack on Concrete: Separating Myths From Reality.” Concrete International, (August), 57-61.

Mindess, S., Young, F. J., and Darwin, D. (2003). Concrete. Pearson Education, Inc., Upper Saddle River, NJ.

Neville, A. M. (1998). Properties of Concrete. John Wiley \& Sons, Inc., New York.

Quercia, G., and Brouwers, H. J. H. (2010). "Application of nano-silica (nS) in concrete mixtures." 8th fib PhD Symposium in Kgs, Lyngby, Denmark.

Richardson, M. G. (2002). Fundamentals of Durable Reinforced Concrete. Spon Press, New York, NY.

Sanchez, F., and Sobolev, K. (2010). "Nanotechnology in concrete - A review." Construction and Building Materials, Elsevier Ltd, 24(11), 2060-2071.

Senff, L., Hotza, D., Repette, W. L., Ferreira, V. M., and Labrincha, J. a. (2010). "Effect of nanosilica and microsilica on microstructure and hardened properties of cement pastes and 
mortars." Advances in Applied Ceramics, 109(2), 104-110.

Singh, L. P., Karade, S. R., Bhattacharyya, S. K., Yousuf, M. M., and Ahalawat, S. (2013). "Beneficial role of nanosilica in cement based materials - A review." Construction and Building Materials, Elsevier Ltd, 47(10), 1069-1077.

Skalny, J., Marchand, J., and Odler, I. (2002). Sulfate Attack On Concrete. Spon Press, London and New York.

Stanish, K. D., Hooton, R. D., and Thomas, M. D. A. (1997). Testing the Chloride Penetration Resistance of Concrete : A Literature Review. Toronto, Ontario, Canada.

Tobón, J. I., Payá, J., and Restrepo, O. J. (2015). "Study of durability of Portland cement mortars blended with silica nanoparticles." Construction and Building Materials, 80(4), 92-97.

Tumidajski, P. J., and Turc, I. (1995). "A Rapid Test for Sulfate Ingress Into Concrete.” Cement and Concrete Composites, 25(5), 924-928.

Wee, T. H., Wee, T. H., Suryavanshi, A. K., Suryavanshi, A. K., Wong, S. F., and Wong, S. F. (2000). "Sulfate resistance of concrete containing mineral admixtures." 97(5), 536-549.

Winter, N. B. (2012). Understanding Cement. WHD Microanalysis Consultants Ltd., Woodridge, UK. 